\title{
The Newberry Deep Drilling Project (NDDP) workshop
}

\author{
Alain Bonneville ${ }^{1,3}$, Trenton T. Cladouhos ${ }^{2}$, Susan Petty $^{2}$, Adam Schultz $^{3,1}$, Carsten Sørlie $^{4}$, \\ Hiroshi Asanuma ${ }^{5}$, Guðmundur Ómar Friðleifsson ${ }^{6}$, Claude Jaupart ${ }^{7}$, and Giuseppe de Natale ${ }^{8}$ \\ ${ }^{1}$ Pacific Northwest National Laboratory, Richland, WA, USA \\ ${ }^{2}$ AltaRock Energy, Seattle, WA, USA \\ ${ }^{3}$ Oregon State University, College of Earth, Ocean and Atmospheric Sciences, Corvallis, OR, USA \\ ${ }^{4}$ Equinor, Stavanger, Norway \\ ${ }^{5}$ AIST - National Institute of Advanced Industrial Science and Technology, Tsukuba, Japan \\ ${ }^{6}$ HS Orka, Svartsengi, Iceland \\ ${ }^{7}$ Institut de Physique du Globe de Paris, Paris, France \\ ${ }^{8}$ INGV - Osservatorio Vesuviano, Naples, Italy \\ Correspondence: Alain Bonneville (alain.bonneville@pnnl.gov)
}

Received: 8 April 2018 - Revised: 27 September 2018 - Accepted: 4 October 2018 - Published: 22 October 2018

\begin{abstract}
The important scientific questions that will form the basis of a full proposal to drill a deep well to the ductile-brittle transition zone $\left(T>400^{\circ} \mathrm{C}\right)$ at Newberry Volcano, central Oregon state, USA, were discussed during an International Continental Drilling Program (ICDP) sponsored workshop held at the Oregon State University-Cascades campus in Bend, Oregon, from 10 to 13 September 2017. Newberry Volcano is one of the largest geothermal heat reservoirs in the USA and has been extensively studied for the last 40 years. The Newberry Deep Drilling Project (NDDP) will be located at an idle geothermal exploration well, NWG 46-16, drilled in $2008,3500 \mathrm{~m}$ deep and $340-374^{\circ} \mathrm{C}$ at bottom, which will be deepened another 1000 to $1300 \mathrm{~m}$ to reach $500^{\circ} \mathrm{C}$. The workshop concluded by setting ambitious goals for the NDDP: (1) test the enhanced geothermal system (EGS) above the critical point of water, (2) collect samples of rocks within the brittle-ductile transition, (3) investigate volcanic hazards, (4) study magmatic geomechanics, (5) calibrate geophysical imaging techniques, and (6) test technology for drilling, well completion, and geophysical monitoring in a very hightemperature environment. Based on these recommendations, a full drilling proposal was submitted in January 2018 to the ICDP for deepening an existing well. The next steps will be to continue building a team with project, technology, and investment partners to make the NDDP a reality.
\end{abstract}

\section{Introduction/workshop objectives}

An International Continental Drilling Program (ICDP) sponsored workshop was held in Bend, Oregon, USA, from 10 to 13 September 2017 with the main goal of discussing the elements of a full proposal for drilling to the ductile/brittle transition zone $\left(T>400^{\circ} \mathrm{C}\right)$ at Newberry Volcano, central Oregon state, in the Cascades volcanic arc of the US Pacific Northwest (Fig. 1). During the 4-day workshop, which included a field trip to the Newberry Caldera and the geothermal test facility, the 55 participants from 11 countries explored several important scientific questions that would form the basis of a full drilling proposal. The full agenda and the list of participants can be found on the ICDP website (https://www.icdp-online.org/projects/world/ north-and-central-america/newberry/, last access: 10 October 2018). The main research goals are related to heat and mass transfer in the crust from the point of view of natural hazards and geothermal energy: enhanced geothermal system (EGS supercritical and beyond-brittle), volcanic hazards, mechanisms of magmatic intrusions, geomechanics close to a magmatic system, calibration of geophysical imaging techniques and drilling in a high-temperature environment.

Drilling at Newberry will bring additional information to a very promising field of research initiated by the Deep Drilling project in Iceland with IDDP-1 on Krafla in 2009 


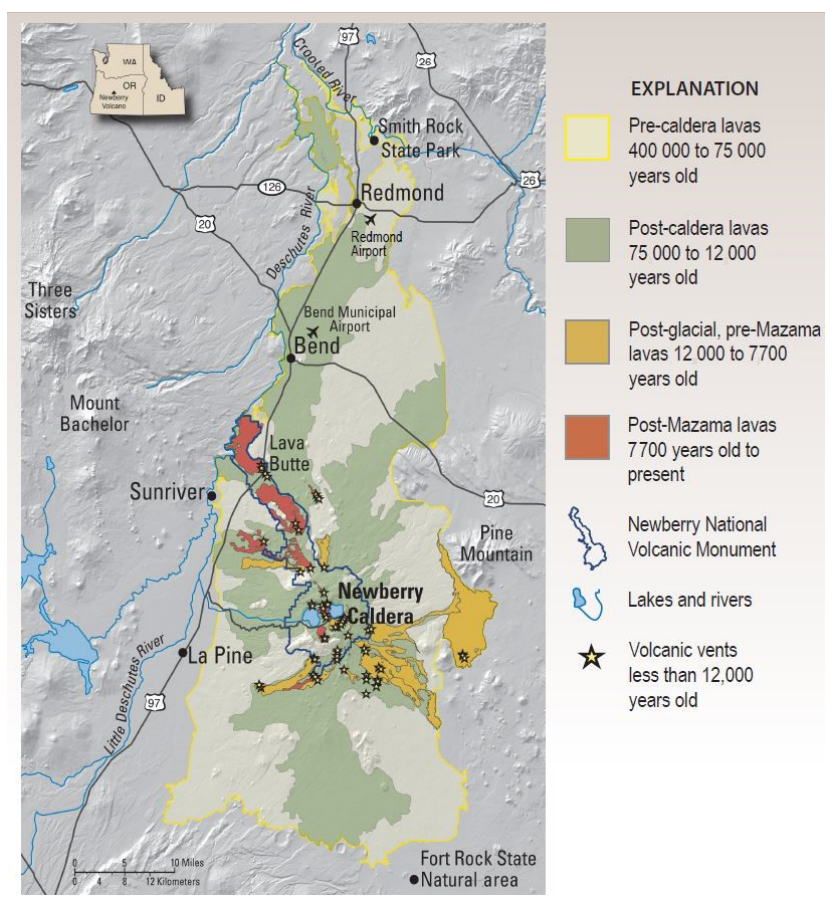

Figure 1. Lava flows and young volcanic vents at Newberry Volcano. The USGS continues to study and monitor the area (from Donnelly-Nolan et al., 2011). Figure 2 below shows the position of the NDDP target well.

(Friðleifsson et al., 2014a), followed by IDDP-2 on the Reykjanes ridge (Friðleifsson et al., 2014b) in 2016, DESCRAMBLE in Italy (Bertani et al., 2018) in 2017, in the future Krafla Magma Drilling Project (John Eichelberger, personal communication, 2017), and the future Japan Beyond-Brittle project (Asanuma et al., 2015; Muraoka et al., 2014). The main results and progress of these important projects were presented by their principal investigators during the workshop.

\section{Newberry Volcano}

\subsection{Geology}

Newberry Volcano is a broad shield volcano (Williams, 1935) that has been active for approximately the last 600000 years (MacLeod et al., 1982; Jensen, 2006). The volcano constructed an elliptically shaped massif approximately $50 \mathrm{~km}$ by $30 \mathrm{~km}$, and some lava flows reach more than $64 \mathrm{~km}$ to the north of the caldera (Fig. 1). Infrequent, widely distributed boulders with exotic lithologies interpreted to be glacial erratics (Donnelly-Nolan and Jensen, 2009) may indicate the presence of a glacier at the summit prior to the cataclysmic eruption at $\sim 75 \mathrm{ka}$ that created the current caldera.

The more gently sloped lower flanks are composed of ash and lahar deposits, basaltic lava, cinder cones, and minor silicic domes. Several basalt flows sourced from the North- west Rift located $100 \mathrm{~km}$ southwest of the proposed ICDP drill site are younger than 7000 years, the age of the regionally extensive Mazama ash from Crater Lake (McKay et al., 2009). The more steeply sloped upper flanks of the volcano are composed predominantly of overlapping silicic domes and subordinate basaltic rock. The central caldera formed $\sim 75000$ years ago is about $8 \mathrm{~km}$ by $5 \mathrm{~km}$ in extent, and is now a nested composite of craters and vents containing two lakes: Paulina Lake to the west at an elevation of $1930 \mathrm{~m}$ and East Lake to the east at an elevation of $1941 \mathrm{~m}$. The Big Obsidian Flow represents the most recent eruption in the caldera, which occurred between 1.6 and $1.3 \mathrm{ka}$. The elevation of the rim of the caldera ranges from 2133 to $2408 \mathrm{~m}$, except along the breached western side, where the elevation is $1929 \mathrm{~m}$.

\subsection{Geothermal}

Newberry Volcano contains one of the largest geothermal heat reservoirs in the western United States, and has been extensively studied for the last 40 years (Bargar and Keith, 1999; Frone, 2015; Sammel et al., 1988; Swanberg et al., 1988). All the knowledge and experience collected make this an excellent choice for drilling a well that will reach high temperatures $\left(>450^{\circ} \mathrm{C}\right)$ at relatively shallow depths $(<5000 \mathrm{~m})$. The large conductive thermal anomaly $\left(320^{\circ} \mathrm{C}\right.$ at $3000 \mathrm{~m}$ depth) has already been well characterized by extensive drilling and geophysical surveys (Cladouhos et al., 2016; Mark-Moser et al., 2016). Four deep (more than $3000 \mathrm{~m}$ deep) boreholes completed in the geothermal lease area on the western flank of the volcano have shown that a natural hydrothermal system is not present outside the caldera, although geothermal hot springs do exist inside the large caldera to the east. Outgassing of magmatic $\mathrm{CO}_{2}$ at one of the deep wells suggests some degree of connectivity exists between deeper magma bodies, possibly those mapped through seismic tomograms beneath the caldera, and the otherwise impermeable western flank geothermal leasehold area. Three large $\left(20000 \mathrm{~m}^{2}\right)$ geothermal pads exist on the geothermal leasehold and eight monitoring boreholes drilled up to $289 \mathrm{~m}$ deep have been used for sampling of shallow groundwater and for continuous seismic monitoring since 2012. In addition to the geothermal conditions appropriate for conventional and super-critical EGS, the prospect of geothermal energy research and development at the Newberry Deep Drilling Project (NDDP) site has the strong support of all the local communities eager for the economic boost that geothermal energy would bring to the area. That support has arisen through many years of public outreach and engagement during the Newberry EGS demonstration and monitoring projects (Cladouhos et al., 2012) that preceded the ICDP workshop at the OSU-Cascades campus in Bend.

A robust conceptual geologic model was developed in 2016 during phase 1 of the US DOE FORGE program (PNNL, 2016). A 3-D model, developed using the 
EarthVision $^{\mathrm{TM}}$ software environment, provides a unified framework which identifies the geological units, constrains their spatial extent, and characterizes properties of relevance to well deepening and geothermal exploration. In the conceptual model, the temperature profile is constrained by borehole equilibrium temperature measurements from deep wells, backed by thermal conductivity measurements of rock cores and cuttings. Additional constraints on porosity and permeability were inferred from seismic, 3-D gravity and 2$\mathrm{D}$ and 3-D magnetotelluric (MT) models. Fluid content at the site is limited to a shallow aquifer or aquifers that extend to depths of 150 to $300 \mathrm{~m}$ below ground surface, beneath which increasing alteration of the volcanic minerals to clays, zeolites, and other moderate-temperature minerals decreases permeability substantially to form a thick low-permeability zone, as observed in cores, well logs, mud logs, and electrical resistivity values. Structural characteristics have been defined by decades of geologic studies, recent high-resolution lidar (light detection and ranging) mapping, seismic tomographic and waveform modeling, MT and gravity inversions, and by ground deformation monitoring. The stress regime has been evaluated by regional seismic focal mechanism studies, by interpretation of faults and volcanic features aligned along structural controls, borehole breakouts, and by simulations carried out during the US Department of Energy supported Newberry EGS Demonstration Project (Cladouhos et al., 2016). This conceptual geologic model and update of the site characterization inventory demonstrate that Newberry Volcano is one of the most extensively characterized EGS sites in the USA, making it an ideal location for implementation of an ICDP drilling project.

AltaRock Energy holds over 9000 acres of the Bureau of Land Management (BLM) geothermal leases on the northwestern flank of Newberry (Fig. 2). The leased area includes two deep geothermal wells, three large drilling pads, two water wells, and connecting roads. AltaRock Energy has permits in hand to drill an additional geothermal well and to carry out extensive microseismic monitoring. Oregon State University has permits in hand to carry out large array MT, controlled-source electromagnetic, gravimetric and ground deformation monitoring. Workovers or deepening of either existing well can be approved through a sundry notice to the BLM.

The two geothermal wells within the geothermal lease, NWG 46-16 and NWG 55-29 on pads 16 and 29 (Fig. 2), have conductive thermal gradients of $110^{\circ} \mathrm{C} \mathrm{km}^{-1}$ starting at $300 \mathrm{~m}$ and continuing to TD, with bottom hole temperatures of over $310^{\circ} \mathrm{C}$ at $3000 \mathrm{~m}$; thus, $500^{\circ} \mathrm{C}$ can be expected at depths below $5000 \mathrm{~m}$ in either well. Unlike wells drilled in many conventional, fracture-dominated geothermal resources, these wells were drilled with full returns; that is, all cuttings were returned to the surface for analysis. Thus, we expect that successfully getting samples out of a deeper hole will be a high probability.

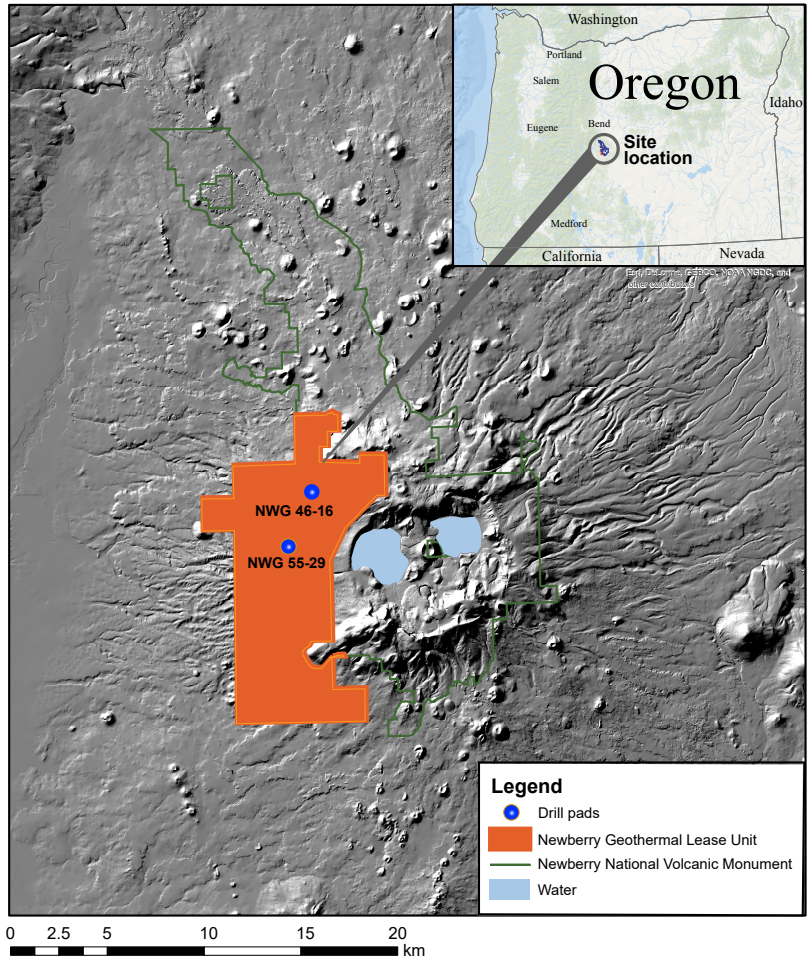

Figure 2. Location of the proposed NDDP well at NWG 46-16. Well NWG 55-29, the Newberry National Volcanic Monument and the geothermal lease are also indicated.

\section{Critical scientific and technical questions and strategies to address them through the NDDP}

\subsection{EGS (supercritical and beyond-brittle)}

Going deeper than existing wellbores at Newberry, for the first time into the brittle-ductile transition, will test the efficiency of thermally induced fracturing and reservoir creation during the drilling stage. The drilling fluid temperature should remain below $200{ }^{\circ} \mathrm{C}$ in order to cool drill bits and logging equipment, which will induce a thermal shock while drilling into hot rocks with temperatures above $400^{\circ} \mathrm{C}$.

In addition, a post-drilling hydraulic well stimulation will both change the pore pressure in fractures and cool the fracture walls. The extent of thermal fracturing and the associated changes in the permeability of the formation remain a big unknown in this kind of thermally activated EGS. Understanding and predicting these processes constitute important factors for development of geothermal energy from supercritical steam $\left(>374^{\circ} \mathrm{C},>22 \mathrm{MPa}\right)$.

From the standpoint of scientific drilling, the primary goal is to characterize the thermal, hydrologic, mechanical and chemical environment needed to design and execute eventual geothermal success at supercritical conditions, and to do so in a continental setting characteristic of the trans-Pacific ring-of-fire as well as analogous volcanic arc and rift regions. 
The NDDP is an initial step towards a commercially viable supercritical EGS project, which would lead to a step change in energy per well, from 5 to $50 \mathrm{MW}$ (Cladouhos et al., 2018), and a commensurate, significant drop in cost per MWh in energy produced.

\subsection{Collect samples of rocks within the brittle-ductile transition}

The IDDP-2 well in Iceland successfully collected some core at temperatures above $400{ }^{\circ} \mathrm{C}$. The mafic rocks from the IDDP-2 hole are not yet ductile as the brittle-ductile transition (BDT) temperature in rocks is heavily dependent on silica content. Spot core samples were collected from the deep well at Kakkonda, including one that contained the Kakkonda granite (Muraoka et al., 1998). NWG 46-16D will present the rare opportunity to collect silica-rich core (likely young granodiorite) from within the BDT. Note that at the expected temperature, it is anticipated that silica-rich rock will be ductile at tectonic strain rates, but not necessarily for drilling and well stimulation strain rates.

\subsection{How Newberry Volcano works}

The U.S. Geological Survey (USGS) considers Newberry Volcano to be a very high-threat volcano because of its recent volcanic activity (within the past 1500 years) in an area where numerous people live. According to a USGS fact sheet, which calls Newberry Volcano a "Sleeping Giant" (Donnelly-Nolan at al., 2011), the volcano hazards at Newberry include

- lava flows,

- ash, pumice, and cinders,

- pyroclastic flows, and

- earthquakes and faulting.

In the recent geologic history of Newberry Volcano there is clear evidence of each of these hazards. For example, eruptions of hot ash, pumice, and gases formed a pyroclastic flow deposit about 75000 years ago as part of the eruption that created Newberry Caldera.

If drilling under or within a National Volcanic Monument were not precluded by US law, a directionally drilled well targeted towards the magma chamber under the center of the caldera, either through long-reach inclined drilling or from directly above, would probably be the best option from a volcanological point of view. A sub-vertical drill hole outside the monument boundary (the approach used for existing wells 46-16 and 55-29) is an excellent alternative that satisfies the other goals of the project as well as permitting requirements, while providing a high-resolution lithologic column with radiometric dates through deeper formations of the volcano where dykes and intrusions associated with prior eruptions will be intersected. This will help characterize the extent and periodicity of major and minor eruptions in the past and determine the likelihood of their future occurrence. Cores taken in this zone, along with testing and logging, will aid in understanding rock mechanical behavior and the stress regime in the brittle-ductile transition zone where eruptive events originate (see sections below). A deeper thermal profile will also provide an essential constraint for improved thermal models of magmatic systems. In situ measurements of minimum principal stress direction and magnitude are critical for geomechanical models, models of eruption triggering, and models of earthquake triggering. Since there are few direct measurements of stress magnitude in the Cascades, this would be of broad relevance to other magmatic systems and studies of regional tectonics.

\section{Mechanisms of magmatic intrusions}

The large stratovolcanoes of the Cascades are typically associated with numerous vents that outline large active zones stretching over many kilometers from the axial area (Hildreth, 2007). In some cases, such as the Three Sisters volcanic cluster in Oregon located $\sim 60 \mathrm{~km}$ northwest of Newberry Volcano, three large volcanic cones stand within a few kilometers of one another and have erupted lavas belonging to the same calc-alkaline suite (Hildreth et al., 2012). These neighboring eruption centers are almost certainly connected to one another, indicating that lateral magma transport is able to channel large magma volumes. Incontrovertible evidence of such transport has been described at Mount Katmai, Alaska (Eichelberger and Izbekov, 2000; Hildreth and Fierstein, 2000), and at Krafla volcano, Iceland (Einarsson and Brandsdottir, 1980). Further support for this process is provided by dyke swarms that emanate from a common focal area and that may be traced over more than $20 \mathrm{~km}$ (Odé, 1957). How and at which stage of volcanic activity magmatic plumbing systems grow laterally is an active research concern.

Analysis of surface rock samples at Newberry shows a wide range of igneous rock compositions, dominated by a bimodal concentration of basaltic andesite and rhyodacite. Hundreds of volcanic vents and fissures are located on and adjacent to the volcano, some of which pre-date Newberry. Data from MacLeod et al. (1982), and from deeper temperature boreholes, suggest that the early eruptive history of the edifice was dominated by mafic lava. Over time, the magmatic character changed to the current bimodal basaltic andesite and rhyodacite. The Newberry flows are deposited on older volcanic and clastic sequences, most of which do not outcrop locally. The characterization of these deeper formations will thus be an important objective of the drilling.

In particular, below $2000 \mathrm{~m}$ depth beneath the surface, the Oligocene John Day Formation (37-19 Ma) is intruded by many sills and dykes coming from both the modern and 
ancient magma chambers. This formation is composed of silicic, intermediate, and basaltic volcanic lava flows, rhyolite ash-flow tuff, and dacite to rhyodacite tuffs and alluvial deposits (Robinson et al., 1984). While existing wellbores extend to $\sim 3000 \mathrm{~m}$ depth, a number of dykes and plutonic bodies at depths greater than $3000 \mathrm{~m}$ beneath the western flank are inferred from geophysical data. The current Newberry Caldera formed 75000 years ago, and Newberry Volcano is generally considered to be 600000 years old. The McKay Buttes, 580 000-year old rhyolite domes $10 \mathrm{~km}$ WSW of the current caldera center, are now mostly buried by Newberry lavas. Granodiorite from cuttings in NWG 55-29 were recently dated as $1.9 \mathrm{Ma}$ (much older than Newberry), while granodiorite from another deep well, 86-21, was dated as $385 \mathrm{ka}$ (Newberry aged) (Julie Donnelly-Nolan, personal communication, 2017). Thus, it is likely that the location of today's Newberry Caldera has been preceded by older calderas, and there may have also been older volcanoes at this location with eastward migration of the volcanic center over time. The record of previous magma chambers, volcanoes, and eruption could be preserved in still warm intrusive bodies on the western flank below NWG 46-16. These potential sources of heat have yet to be confirmed by drilling. The identification, characterization and dating of these intrusive bodies, as well as the determination of the main control factors of their emplacement and extension, constitute a major scientific objective that can only be reached by deep drilling. Their role in the fracturing of the host rock and in the dynamics of the overall magmatic system will also be considered.

\subsection{Geomechanics close to a magmatic system}

The geometry and orientation of structural features, such as fractures, faults, and dykes, on a volcano are a function of the in situ stresses, which are likely to be heterogenous both spatially and temporarily. Likewise, successful design and execution of an EGS project on a volcano will depend upon accurate knowledge of the stress regime. Stress models have been a challenge at EGS projects associated with volcanic systems in the past, starting at Fenton Hill (see the recent reanalysis by Norbeck et al., 2018) and continuing with Hijiori and Ogachi basin (Kaieda et al., 2010). Even at conventional geothermal fields in extensional regimes (i.e., Dixie Valley, Hickman et al., 1998), the stress can be heterogeneous in a single well. A mini-frac test, or extended leak-off test, is a pressurized in situ stress test that provides information about a rock reservoir's permeability, mechanical strength, and especially the minimum principal stress. Developing and testing new, more reliable and easily performed methods of measuring stress in geothermal wells will be an important $R \& D$ result.

\subsection{Calibration of geophysical imaging techniques}

The conceptual geological model built on independent geophysical observations and models includes large intrusive bodies below the deepest wells in the western flank of Newberry. Drilling a well to $\sim 5 \mathrm{~km}$ will allow verification of these interpretations, as well as validation of bounds placed on the temperature and permeability of these deeper formations. This will help define the best imaging tools that could be deployed in such a geological context, their optimal resolution, as well as their distribution in the field. This will have enormous value for future geophysical exploration and EGS monitoring efforts, and for understanding of the evolution of volcanic systems and related volcanic hazards.

\subsection{Drilling and geophysical monitoring in a high-temperature environment}

Drilling in very high-temperature environments, potentially with supercritical fluids, is a difficult task as demonstrated by the IDDP-1 experiment (Pálsson et al., 2014) and requires special drilling bits, drill string, casing and cement, as well as a rigorous environmental, health, and safety plan. The most innovative techniques available on the market at the time of the drilling will be evaluated and tested. In particular, the technique for collecting core samples (i.e. spot cores or continuous wireline coring) needs further evaluation during the pre-drilling phase of the project. Well deviation, temperature, ability to cool the well through circulation and the hourly rig cost during coring will be critical factors that will be analyzed in choosing a coring method. Another issue related to the extreme temperature is the mechanical behavior at the drill face, that is, whether the brittle-ductile transition can be detected.

Downhole geophysical tools should also have exceptional tolerance at high temperatures and pressures, and durability in chemically aggressive fluid environments (Ásmundsson et al., 2014). For example, what is the extreme limit of deployment of fiber-optic based technologies that are now increasingly used in subsurface projects? During the NDDP, we propose to test different instruments and methods like high-temperature fiber-optic microseismic arrays, distributed well monitoring for production, and deep borehole electrical resistivity tomography (ERT) electrodes.

\subsection{Why drilling?}

It will be extremely challenging to drill rocks hotter than $450^{\circ} \mathrm{C}$. Above the critical point of water, flow-back fluids will be much more corrosive and dangerous, requiring special casing and wellhead alloys. Some rocks will begin to exhibit ductile behavior, making drilling and injection testing more unpredictable. Instruments that can withstand these conditions are limited and expensive.

As described above, the goals of the NDDP are to (1) test the EGS above the critical point of water, (2) collect sam- 
ples of rocks within the brittle-ductile transition, (3) investigate volcanic hazards, (4) study magmatic geomechanics, (5) calibrate geophysical imaging techniques, and (6) test technology for drilling and geophysical monitoring in a high-temperature environment. None of these goals can be achieved in a laboratory or otherwise without drilling. Drilling is the only way to prepare a hole for testing a largescale EGS at supercritical temperatures. Drilling is the only way to collect in situ materials (cuttings, core, fluids) through the BDT. Drilling is the only way to measure in situ properties that control volcanic hazards such as principal stress magnitudes and orientation. Drilling is the only way to test in situ geomechanics by perturbing the rock mass through well stimulation. Drilling is ultimately the only way to test drilling equipment and casing outside of the lab, to refine and prove the technologies that will be needed to develop Super Hot Geothermal projects.

\section{Scope of the proposed drilling}

The Newberry Deep Drilling Project will be located at an idle geothermal exploration well, NWG 46-16, drilled in 2008, $3500 \mathrm{~m}$ deep and $340-374^{\circ} \mathrm{C}$ at bottom, which will be deepened another 1000 to $1300 \mathrm{~m}$ to reach $500^{\circ} \mathrm{C}$ into the supercritical region, and potentially approaching the brittleductile transition or even zones of partial melt. The original well was drilled with few lost circulation zones and the temperature profile indicates conductive heat flow. Compared to other Super Hot Geothermal projects worldwide (e.g., Reinsch et al., 2017), this well would return more materials (cuttings, core and fluids) with more predictable drilling conditions, thus providing a suite of data near and across the brittle-ductile transition in silica-rich rocks. After drilling, a hydraulic well stimulation will both change the pore pressure in fractures and cool the fracture walls, resulting in permeability enhancement through both thermal fracturing and hydro-shearing. Zonal isolation resistant to this temperature range will be developed and tested.

Geothermal, volcanic, geophysical, and engineering information gained will be widely applicable across the Cascade volcanic arc, as well as other magmatically active areas throughout the Pacific Rim and beyond. 46-16D will be completed with casing and cement designed and tested to withstand the abuses of thermal cycling, hydraulic and thermal stimulation, and flow of supercritical fluids.

A detailed plan with contingencies will be developed during the pre-drilling planning and qualification phase of the project. Details below are subject to change based on further data analysis and technological review. Pre-drilling due diligence for risk assessment will include mechanical integrity testing of the existing $34 \mathrm{~cm}$ (13.375-inch) casing and investigation with a camera run of a blockage at $1525 \mathrm{~m}$ that formed during a flow test in October 2008 and then was easily re-opened by a drill bit. Then, depending on the nature of blockage, a workover rig will be brought in to clean it out and potentially case off the unstable zone.

The preliminary drilling and completion plan is to deepen the well to at least $3750 \mathrm{~m}$ with $31.12 \mathrm{~cm}$ (12.25-inch) bits, the depth at which a temperature of $374{ }^{\circ} \mathrm{C}$ (the critical point of pure water) is expected. Then the well will be cased with $24.45 \mathrm{~cm}$ (9.625-inch) casing tied back to the surface. The detailed procedures, and casing and grouting materials, for this very challenging step will be developed and independently reviewed during the pre-drilling planning and qualification phase of the project. The hole will be deepened to an expected depth of $4877 \mathrm{~m}$ and temperature of $500^{\circ} \mathrm{C}$. Based on geophysical models (Bonneville et al., 2017), 46$16 \mathrm{D}$ is expected to intersect granitic rocks between the current TD and $4000 \mathrm{~m}$. Cores will be collected at regular intervals and stress measurements as allowed by the technology and drilling conditions. A $17.78 \mathrm{~cm}$ (7-inch) perforated liner will be installed in the open hole interval, 3650 to $4877 \mathrm{~m}$. After well completion, a 2-week rig-on hydraulic and thermal stimulation will be performed with design parameters informed by core analysis, THMC modeling, and laboratory testing. EGS creation will be monitored by an improved micro-seismic network as well as by surface and borehole geophysical methods (MT, ERT, InSAR, microgravity). To finish, a single-well flow-back test will be performed to determine well permeability and EGS success.

\section{Future development}

For 15 January 2019, the authors plan to submit a full drilling proposal to ICDP which will incorporate most of the results of the thorough discussions held during the workshop. If accepted, this proposal would cover part of the funding for the scientific aspects of drilling. In addition to that, the project team has developed an extensive, multi-pronged plan for obtaining the remainder of the funding from public agencies and a variety of interested parties. For the purposes of management and investment, the fundraising will be separated into three categories: technology, science and development.

Data availability. Most data supporting the work presented in this report are available in the US Department of Energy Geothermal Data Repository (GDR): https://gdr.openei.org/home, last access: 10 October 2018.

Competing interests. The authors declare that they have no conflict of interest.

Acknowledgements. The authors want to sincerely thank all the participants in the workshop. We also thank the ICDP, which covered all the travel and lodging expenses, Oregon State University Cascades campus for hosting the workshop on their 
premises and Julie Donnelly-Nolan from USGS as well as Alta Rock for the organization of the field trip. We want also to thank Pat Dobson and Thomas Reinsch for their careful review. This is Information Release no. PNNL-SA-133670.

Edited by: Thomas Wiersberg

Reviewed by: Patrick Dobson and Thomas Reinsch

\section{References}

Asanuma, H., Tsuchiya, N., Muraoka, H., and Ito, H.: Japan Beyond-Brittle Project: Development of EGS Beyond BrittleDuctile Transition, Proceedings World Geothermal Congres, Melbourne, Australia, 2015.

Ásmundsson, R., Pezard, P., Sanjuan, B., Henninges, J., Deltombe, J.-L., Halladay, N., Lebert, F., Gadalia, A., Millot, R., Gibert, B., Violay, M., Reinsch, T., Naisse, J.-M., Massiot, C., Azaïs, P., Mainprice, D., Karytsas, C., and Johnston, C.: High temperature instruments and methods developed for supercritical geothermal reservoir characterisation and exploitation - The HiTI project, Geothermics, 49, 90-98, 2014.

Bargar, K. E. and Keith, T. E. C.: Hydrothermal Mineralogy of Core from Geothermal Drill Holes at Newberry Volcano, Oregon, USGS Professional Paper 1578, p. 92, 1999.

Bertani, R., Busing, H., Buske, S., Dini, A., and the DESCRAMBLE Science and Technology Team: The First Results of the DESCRAMBLE Project, 43rd Workshop on Geothermal Reservoir Engineering, Stanford University, Stanford, California, 2018.

Bonneville, A., Cladouhos, T. T., Rose, K., Schultz, A., Strickland, C., and Urquhart, S.: Improved image of intrusive bodies at Newberry Volcano, Oregon, based on 3D gravity modelling, 42nd Workshop on Geothermal Reservoir Engineering Stanford University, Stanford, California, 2017.

Cladouhos, T. T., Osborn, W. L., and Petty, S.: Newberry Volcano EGS Demonstration - Phase I Results, 37th Workshop on Geothermal Reservoir Engineering, Stanford University, Stanford, California, 2012.

Cladouhos, T. T., Petty, S., Swyer, M. W., Uddenberg, M. E., Grasso, K., and Nordin, Y.: Results from Newberry Volcano EGS Demonstration, 2010-2014, Geothermics, 63, 44-61, 2016.

Cladouhos, T. T., Petty, S., Bonneville, A., Schultz, A., and Sorlie, C.: Super Hot EGS and the Newberry Deep Drilling Project, 43rd Workshop on Geothermal Reservoir Engineering, Stanford University, Stanford, California, 2018.

Donnelly-Nolan, J. M. and Jensen, R. A.: Ice and water on Newberry Volcano, central Oregon, Field Guides, 15, 81-90, 2009.

Donnelly-Nolan, J. M., Stovall, W. K., Ramsey, D. W., Ewert, J. W., and Jensen, R. A.: Newberry Volcano - central Oregon's sleeping giant, U.S. Geological Survey Fact Sheet, 2011-3145, 6 pp., 2011.

Eichelberger, J. C. and Izbekov, P. E.: Eruption of andesite triggered by dyke injection: contrasting cases at Karymsky Volcano, Kamchatka and Mt Katmai, Alaska, Proc. R. Soc. London A, 358, 465-461, 485, 2000.

Einarsson, P. and Brandsdottir, B.: Seismological Evidence for Lateral Magma Intrusion During the July 1978 Deflation of the Krafla Volcano in NE-Iceland, J. Geophys. Res., 47, 160-165, 1980.
Friðleifsson, G. Ó., Elders, W. A., and Albertsson, A.: The concept of the Iceland deep drilling project, Geothermics, 49, 2-8, 2014a.

Friðleifsson, G. Ó., Sigurdsson, Ó., Porbjörnsson, D., Karlsdóttir, R., Gíslason, P., Albertsson, A., and Elders, W. A.: Preparation for drilling well IDDP-2 at Reykjanes, Geothermics, 49, 119126, 2014b.

Frone, Z.: Heat Flow, Thermal Modeling And Whole Rock Geochemistry of Newberry Volcano, Oregon and Heat Flow Modeling of The Appalachian Basin, West Virginia, PhD Thesis, Southern Methodist University, p. 262, 2015.

Hickman, S., Zoback, M., and, Benoit, R.: Tectonic controls on reservoir permeability in the Dixie Valley, Nevada, geothermal field, 23rd Workshop on Geothermal Reservoir Engineering, Stanford University, Stanford, California, 1998.

Hildreth, W.: Quaternary Magmatism in the Cascades - Geologic Perspectives, US Geol. Surv. Prof. Paper, 1744, 2007.

Hildreth, W. and Fierstein, J.: Katmai volcanic cluster and the great eruption of 1912, Geol. Soc. Am. Bull., 112, 1594-1620, 2000.

Hildreth, W., Fierstein, J., and Calvert, A.: Geologic map of the Three Sisters volcanic clusters, Cascade Range, Oregon, U.S. Geol. Surv. Scientific Investigations, Map 3186, 2012.

Jensen, R. A.: Roadside guide to the geology and history of Newberry Volcano, CenOreGeoPub, Bend, OR, 2006.

Jensen, R. A., Donnelly-Nolan, J. M., and McKay, D.: A field guide to Newberry Volcano, Oregon, in: Volcanoes to vineyards: geologic field trips through the dynamic landscape of the Pacific Northwest, editd by: O'Connor, J., Dorsey, R. J., and Madin, I. P., Volume 15, Geological Society of America, 53-79, 2009.

Kaieda, H., Sasaki, S., and Wyborn, D.: Comparison of characteristics of micro-earthquakes observed during hydraulic stimulation operations in Ogachi, Hijiori and Cooper Basin HDR projects, Proceedings of the World Geothermal Congress, 2010.

MacLeod, N. S., Sherrod, D. R., and Chitwood, L. A.: Geologic map of Newberry Volcano, Deschutes, Klamath, and Lake Counties, Oregon, p. 27, 1982.

Mark-Moser, M., Schultz, J., Schultz, A., Heath, B., Rose, K., Urquhart, S., Bowles-Martinez, E., and Vincent, P.: A conceptual geologic model for the Newberry Volcano EGS Site in Central Oregon: Constraining heat capacity and permeability through interpretation of multicomponent geosystems data, 41st Workshop on Geothermal Reservoir Engineering, Stanford University, Stanford, California, 2016.

McKay, D., Donnelly-Nolan, J. M., Jensen, R. A., and Champion, D. E.: The post-Mazama northwest rift zone eruption at Newberry Volcano, Oregon, edited by: O’Connor, J. E., Dorsey, R. J., and Madin, I. P., Geological Society of America Field Guide, 15, 91-110, 2009.

Muraoka, H., Uchida, T., Sasada, M., Yagi, M., Akaku, K., Sasaki, M., Yasukawa, K., Miyazaki, S. I., Doi, N., Saito, S., Sato, K., and Tanaka, S.: Deep geothermal resources survey program: igneous, metamorphic and hydrothermal processes in a well encountering $500^{\circ} \mathrm{C}$ at $3729 \mathrm{~m}$ depth, Kakkonda, Japan, Geothermics, 27, 507-534, 1998.

Muraoka, H., Asanuma, H., Tsuchiya, N., Ito, T., Mogi, T., Ito, H., and the participants of the ICDP/JBBPWorkshop: The Japan Beyond-Brittle Project, Sci. Dril., 17, 51-59, https://doi.org/10.5194/sd-17-51-2014, 2014.

Norbeck, J. H., McClure, M. W., and Horne, R. N.: Field observations at the Fenton Hill enhanced geothermal system test site sup- 
port mixed-mechanism stimulation, Geothermics, 74, 135-149, 2018.

Odé, H.: Mechanical analysis of the dike pattern of the Spanish Peaks area, Colorado, Geol. Soc. Am. Bull., 68, 567-576, 1957.

Pálsson, B., Hólmgeirsson, S., Guðmundsson, Á., Bóasson, H. Á., Ingason, K., Sverrisson, H., and Thórhallsson, S.: Drilling of the well IDDP-1, Geothermics, 49, 23-30, 2014.

PNNL: Pacific Northwest National Laboratory Phase 1 Report, a collection of 14 reports submitted for DOE FORGE application, https://energy.gov/eere/forge/downloads/ pacific-northwest-national-laboratory-phase-1-report (last access: 17 September 2018), 2016.

Reinsch, T., Dobson, P., Asanuma, H., Huenges, E., Poletto, F., and Sanjuan, B.: Utilizing supercritical geothermal systems: a review of past ventures and ongoing research activities, Geothermal Energy, 5, 16, https://doi.org/10.1186/s40517-017-0075-y, 2017.
Robinson, P. T., Brem, G. F., and McKee, E. H.: John Day Formation of Oregon: a distal record of early Cascade volcanism, Geology, 12, 229-232, 1984.

Sammel, E., Ingebritsen, S., and Mariner, R.: The hydrothermal system at Newberry volcano, Oregon, J. Geophys. Res., 93, 1014910162, 1988.

Swanberg, C. A., Walkey, W. C., and Combs, J.: Core hole drilling and the "rain curtain" phenomenon at Newberry Volcano, Oregon, J. Geophys. Res., 93, 10163-10173, 1988.

Williams, H.: Newberry volcano of central Oregon, Geol. Soc. Am. Bull., 46, 253-304, 1935. 